\title{
Impact of credit risk (NPLs) and capital on liquidity risk of Malaysian banks
}

\author{
Azlan Ali, Yaman Hajja*, Hafezali Hussain \\ Universiti Kuala Lumpur Business School, Malaysia
}

\begin{abstract}
We investigate the relationship between bank liquidity risk and credit risk and the impact of bank capital on liquidity risk. Using 19 Malaysian commercial banks data over 2002-2011 and applying dynamic panel data GMM estimation after controlling for bank-specific and macroeconomic variables, empirical results document a positive relationship between liquidity and credit risk and a non-linear U-shaped relationship between bank capital and liquidity risk.
\end{abstract}

Keywords: liqudity risk; credit risk; bank capital; Malaysia banking risk.

\section{INTRODUCTION}

The aim of this paper is to answer the questions: what is the relationship between liquidity risk and credit risk in a commercial bank? And what is the impact of bank capital on liquidity risk. Traditional theory of banks, as in Diamond and Dybvig (1983), suggests that credit risk and liquidity risk are related in a close manner as the bank's asset and liability structures are connected. In banking theory, the banks' role is providing liquidity to the economy and to screen and monitor potential borrowers. Banks are thus engaged in the transformation of liquid deposits into illiquid loans (De Haan et al., 2009). In the bank's capital theory which is introduced by Diamond and Rajan (2000), "the optimal bank capital structure trades off the effects of bank capital on liquidity creation, the expected costs of bank distress, and the ease of forcing borrower repayment". However, the contrast between theory and reality is perhaps most apparent in the area of risk management (Allen \& Santomero, 1997).

\section{SELECTED LITERATURE}

Few studies investigate the relationship between credit and liquidity risk in banks. Imbierowicz and Rauch (2014) study the relationship between liquidity risk and credit risk in U.S. commercial banks over 1998-2010 and find no relationship exists between them, they instead find that both (liquidity and credit) risks affect insolvency risk (probability of default Z-score). Distinguin et al. (2013) study the relationship between capital and liquidity risk in quoted US and European banks and find that small banks increase their capital when they face higher illiquidity. Berger and Bouwman (2009) find that the relationship between liquidity risk and capital in US banks is positive for large banks and negative for small banks.

However, Ratnovski (2013) studies liquidity and transparency in bank risk management and models a bank liquidity risk in which banks, in case of solvency problems, cannot refinance its short-term liabilities, the solution is that banks can aggregate buffer of liquid assets, or intensify transparency to communicate solvency.

*Corresponding author. Tel.: +60163662925

E-mail: yaman1978@gmail.com 
In the model, both liquidity buffers and bank transparency are important in bank liquidity risk management, and there are both a need for liquidity requirements to be complemented by measures, and a need for better corporate governance, to improve bank transparency (better communication that enhances access to external refinancing).

\section{HYPOTHESES}

We hypothesise the following two main hypotheses:

$\mathrm{H} 1$ : the relationship between credit risk and liquidity risk is positive.

$\mathrm{H} 2$ : The relationship between bank capitalization and liquidity risk is a non-linear $U$-shaped relationship. That is bank capital initially increases liquidity risk and then, with the bank build-ups, it decreases the bank liquidity risk.

\section{SAMPLE, DATA, AND VARIABLES}

\subsection{Data}

Bank-specific or bank-characteristics data are collected from BankScope database. The sample dataset consists of 19 commercial banks in Malaysia over the period 2002-2011 ${ }^{1}$. The dataset compromises over 190 bank-year observations for each variable. We choose the year of 2002 as a beginning of the time series because at the beginning of 2001, 50 of the 54 banking institutions have been merged into 10 banking groups. Macroeconomic data are collected from World Bank database.

\subsection{Variables}

The dependent variable for this study is the liquidity risk (LR) which is measured by the sum of bank liquid assets divided by customer deposits and short term funding. The proxy of credit risk (CR) is the ratio of nonperforming loans or impaired loans to gross loans. Bank capital (CA) is proxied by total equity to total assets. $\left(\mathrm{CA}^{2}\right)$ is the square term of capital (CA) which is included to test the existence of U-shaped (non-linearity) relationship between bank capitalization and liquidity risk. Macroeconomic control variables include inflation and sovereign (central government) debt which is represented by central government debt scaled to GDP in percentage.

Other bank-specific control variables include the net-interest income variable which is a product of net-interest income scaled to average earning assets, and the ratio of non-interest income scaled to total income as a proxy for income diversification. Bank size is peoxied by natural logarithm of total assets and return on equity as a proxy of bank's management performance equals the ratio of bank's pre-tax profits to total shareholders' equity. The last control variable is the bank inefficiency which is measured as the ratio of bank operating expenses (bank overheads or total non-interest expenses) scaled to the bank's operating income. The ratio measures how the bank is efficient in exploiting its resources. Less value of this ratio denotes more efficiency, and greater value marks higher inefficiency. In banking literature this ratio is called (cost-to-income ratio) and largely used. Table 1 presents the variable definition.

Table 1. Variable Definition.

\begin{tabular}{ll}
\hline Variable & Definition \\
\hline Liquidity risk & Bank liquid assets divided by customer deposits and short term funding \\
\hline Credit risk & Ratio of non-performing loans to gross Loans \\
\hline Capital & Total equity to total assets \\
\hline Capital squared & Square term of (total equity to total assets) \\
\hline Net-interest income & Net-interest income to average earning assets \\
\hline Non-interest income & Non-interest income to total income \\
\hline Size & Natural logarithm of bank's total assets \\
\hline Inefficiency & Bank operating expenses to bank's operating income \\
\hline Return on equity & Ratio of bank's pre-tax profits to total shareholders' equity \\
\hline Inflation & \\
\hline Sovereign debt & Central government debt over GDP \\
\hline
\end{tabular}

\footnotetext{
1 These 19 commercial banks are: Affin Bank Berhad, Alliance Bank Malaysia Berhad, AmBank (M) Berhad, CIMB Bank Berhad, Hong Leong Bank Berhad, Malayan Banking Berhad, Public Bank Berhad, RHB Bank Berhad, Bank of America Malaysia Berhad, Bank of Tokyo-Mitsubishi UFJ (Malaysia) Berhad, Citibank Berhad, Deutsche Bank (Malaysia) Berhad, HSBC Bank Malaysia Berhad, J.P. Morgan Chase Bank Berhad, OCBC Bank (Malaysia) Berhad, Standard Chartered Bank Malaysia Berhad, The Bank of Nova Scotia Berhad, The Royal Bank of Scotland Berhad, and United Overseas Bank (Malaysia) Berhad.
} 


\subsection{Descriptive Statistics}

Fig. 1 depicts the graph for liquidity risk for each of the 19 banks in the sample during the period 2002-2011. Table 2 illustrates the descriptive statistics of this study's variables.

\section{METHODLOGY}

We use a dynamic panel data technique for the research's methodology in order to take into account the unobservable individual bank-specific effects, in addition to take under consideration and to control also for the 'time persistence' in the liquidity risk measure (i.e., the dependent variable) and in other variables as well. We use dynamic panel techniques, the Generalized Method of Moments (GMM) as suggested and introduces firstly by Arellano and Bond (1991) (the Difference GMM) and as Arellano and Bover (1995) and Blundell and Bond (1998) generalize it later (the System-GMM). The model for liquidity risk (LR) is taking the following form:

$$
\mathbf{L R}_{\mathrm{i}, \mathrm{t}}=\mathbf{L R}_{\mathrm{i}, \mathrm{t}-1}+\mathbf{C \mathbf { R } _ { \mathrm { i } , \mathrm { t } }}+\mathbf{C A} \mathbf{A}_{\mathrm{i}, \mathrm{t}-1}+\mathbf{C A}_{\mathrm{i}, \mathrm{t}-1}^{2}+\text { Control Variables }
$$

\begin{tabular}{|c|c|c|c|c|c|}
\hline Variable & Mean & Max. & Min. & Sd. & Skewness \\
\hline Liquidity risk LR & 44.60 & 155.40 & 9.50 & 34.89 & 1.54 \\
\hline Credit risk $\mathrm{CR}$ & 6.54 & 57.33 & 0.08 & 7.47 & 3.18 \\
\hline Capital CA & 10.18 & 35.34 & 3.57 & 6.44 & 2.11 \\
\hline Capital squared $\mathrm{CA}^{2}$ & 144.88 & 1248 & 12.74 & 224.43 & 3.02 \\
\hline Net-interest income & 3.21 & 13.87 & 0.27 & 1.69 & 3.86 \\
\hline Non-interest income & 85.21 & 1425 & -1219 & 163.18 & 1.09 \\
\hline Size $(\log \mathrm{TA})$ & 10.11 & 12.93 & 6.81 & 1.49 & -0.42 \\
\hline Inefficiency & 41.64 & 102.87 & -199 & 21.03 & -7.82 \\
\hline Return on equity ROE & 17.73 & 55.43 & -23.5 & 10.45 & -0.10 \\
\hline Inflation & 4.43 & 10.39 & -5.99 & 4.17 & -1.17 \\
\hline Sovereign debt & 44.99 & 51.57 & 39.80 & 4.48 & 0.38 \\
\hline
\end{tabular}

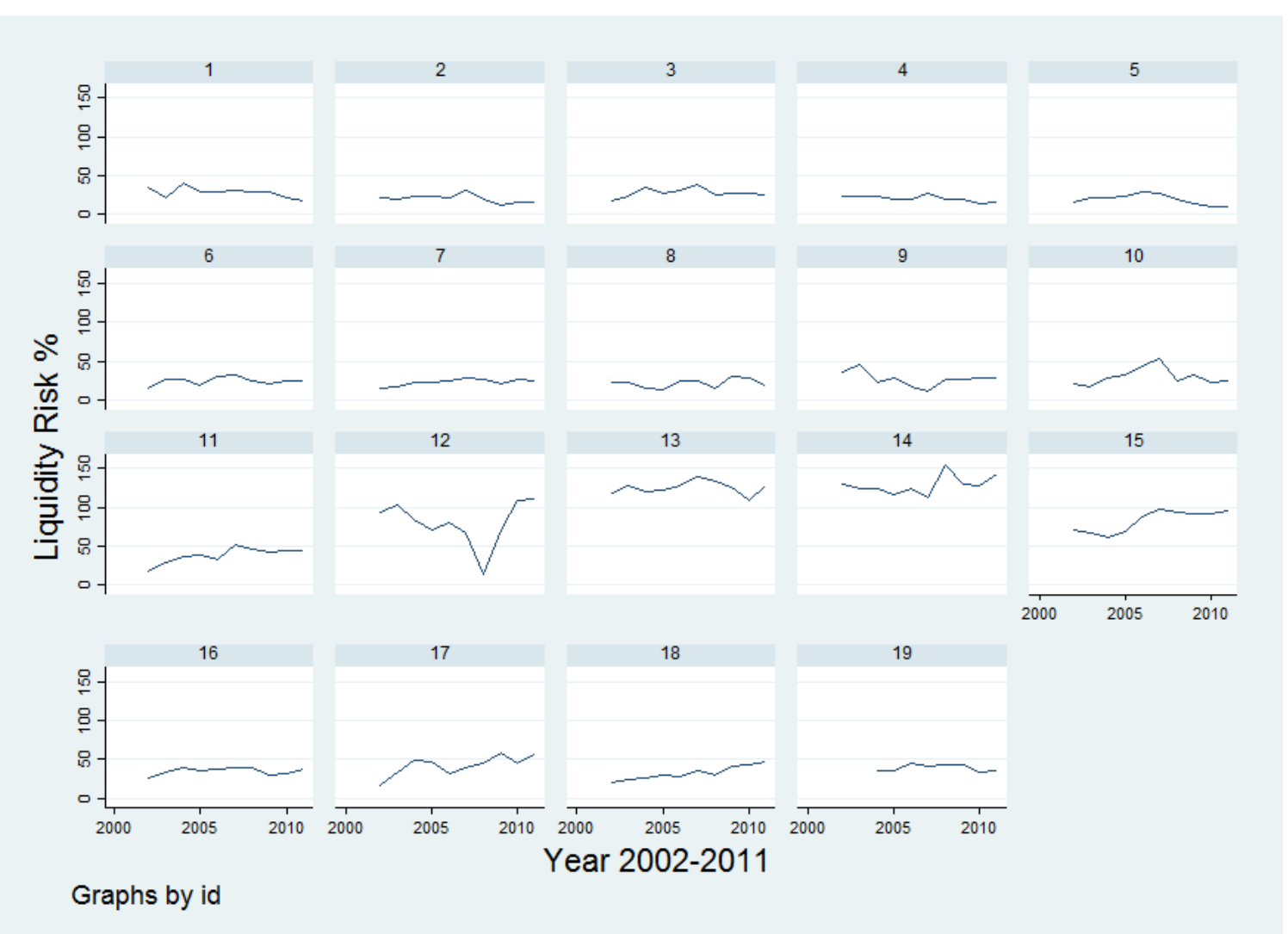

Fig. 1. Banks Liquidity Risk \% 2002-2011.

In Eq. (1), we use two-step GMM estimation method and lagged values of liquidity risk (LR), capital (CA), capital squared $\left(\mathrm{CA}^{2}\right)$, return on equity (ROE), and sovereign debt; and current (contemporaneous) values of 
credit risk (CR), net-interest income, non-interest income, bank size (Log TA), inefficiency, and inflation; are used as an explanatory variables.

The estimated standard errors in the two-step GMM estimation are utilized in order to produce a consistency in the "variance-covariance matrix of the moment conditions" errors of the model (Louzis et al., 2012). However, the two-step estimator of standards errors may impose a downward biased tendency during the estimation (Arellano and Bond, 1995; Blundell and Bond, 1998), yet, Windmeijer (2005) states that "Monte Carlo studies have shown that estimated asymptotic standard errors of the efficient two-step generalized method of moments (GMM) estimator can be severely downward biased in small samples". In this case to face this problem, we use the finite-sample correction of covariance matrix (corrected estimate of the variance) resulting from the two-step method, the correction method proposed by Windmeijer (2005) in order to lead to more accurate statistical inference. Moreover, we use 'robust standard errors' option in STATA software in the two-step GMM estimators to get more efficient and consistent results.

We use Sragan specification test which attests the total validity of the variables instruments used in the model estimation, that is to test the null hypothesis of Sargan test which is "asymptotically distributed moment conditions as chi-square", in other words the null hypothesis of valid moment conditions (Arellano and Bond, 1995; Blundell and Bond, 1998). Sargan test (it is called also Hansen specification test) is used to ensure that the errors (residuals) are not second-order auto correlated, i.e., to test the hypothesis that no second-order serial autocorrelation in errors $\left(\mathrm{m}_{2}\right.$ test). As a rule of thumb in GMM estimation, the number of instruments used should not exceeds the number of groups of cross section units, i.e., the number of banks in the research. This issue is also being under consideration during the GMM estimation.

\section{RESULTS}

Table 3 depicts the empirical results of Arellano-Bond dynamic panel-data two-step GMM estimation for liquidity risk model. $\mathrm{m}_{2}$ test revealed that there are no second-order serial autocorrelation in errors and consequently a valid moments conditions. The model constant is significant at $0.1 \%$ with high coefficients of 148.5049 and the lagged dependent variable is found to be statistically not significant.

The relationship between credit risk and liquidity risk is significantly positive at $0.1 \%$ confidence level. That denotes that more credit risk (more non-performing loans) leads to more liquidity risk and vice versa, i.e., less credit risk tends to decrease liquidity risk.

The sign of the lagged capital coefficient is significantly positive at $5 \%$ level in respect to its effect on liquidity risk. However, the sign of the lagged capital squared is significantly negative at $5 \%$ level, and that suggests that the relationship between bank capital and liquidity risk is non-linear and takes a convex shape or U-shaped relationship. This non-linear U-shaped relationship that exists between capital and liquidity suggests that bank capital is initially increasing the bank liquidity risk and then with the bank capital build-ups it helps decreasing the liquidity risk of the bank.

Coefficient of lagged return on equity variable (ROE) is not statistically significant, implying that bank profitability has nothing to do empirically (or significantly) with the bank liquidity risk. The relationship between bank inefficiency and liquidity risk is significantly negative at $0.1 \%$ level suggestive of that the less inefficiency, the more liquidity risk.

The impact of bank size on liquidity risk is significantly positive at $0.1 \%$ implying that larger banks tend to be more risky (in terms of liquidity risk) and to realize 'too-big-to-fail' argument in terms of liquidity risk as well.

Net-interest income is affecting liquidity risk positively at 5\% level, and non-interest income is affecting liquidity risk negatively at 5\% level. This denotes that more interest based income results in more liquidity risk, and more non-interest income (more income diversification) results in less liquidity risk.

For macroeconomic variables, the relationship between inflation and liquidity risk is significantly negative at 5\% level, and the relationship between (lagged) sovereign debt and liquidity risk is also negative at 5\% confidence level. Macroeconomics variables results may imply that the expansionary phase of the economy (high rates of inflation and sovereign debt) lead to less liquidity risk in the banking system. 
Table 3. Arellano-Bond dynamic panel-data two-step GMM estimation results for liquidity risk model.

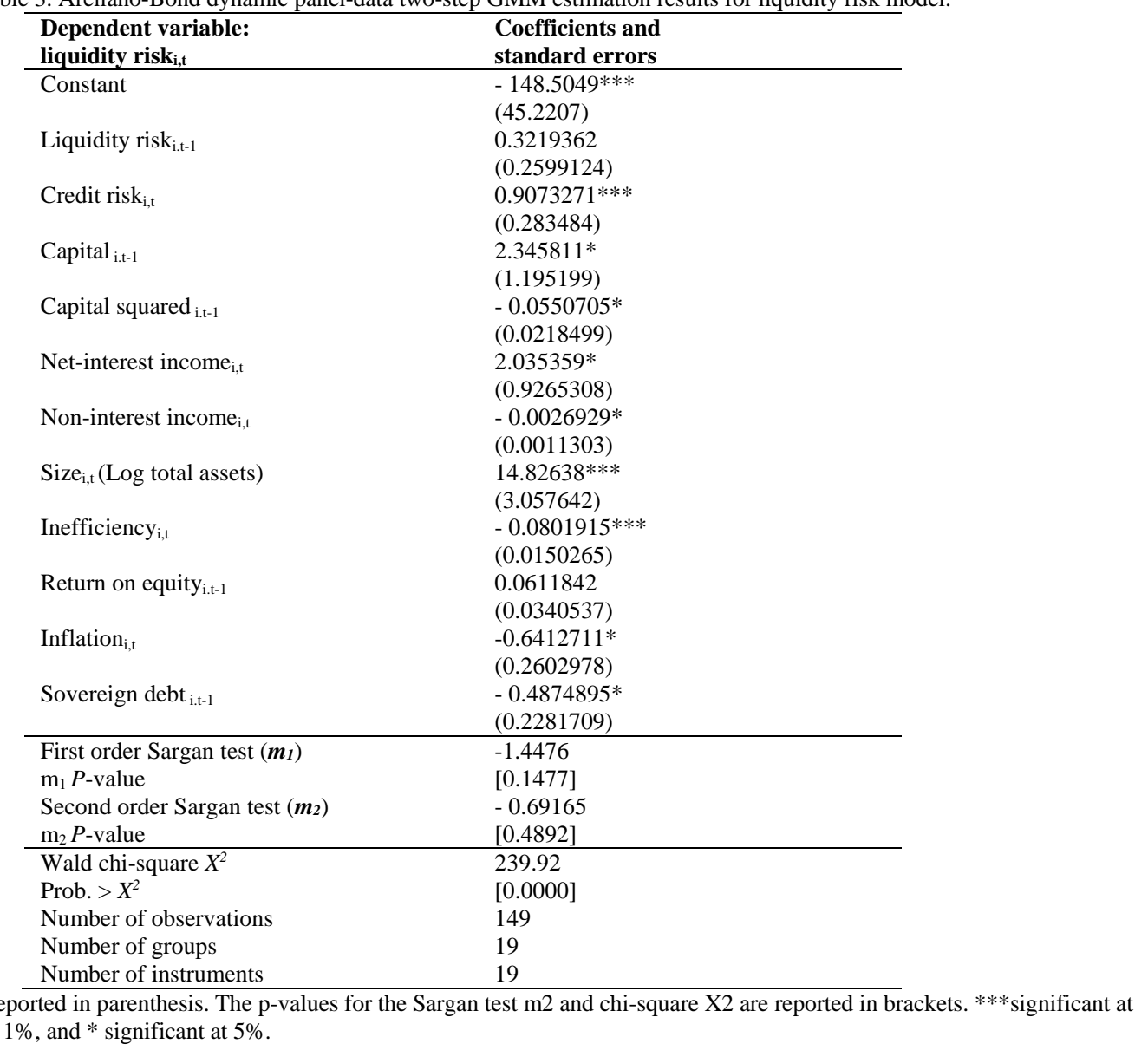

Notes: t-statistics are reported in parenthesis. The p-values for the Sargan test $\mathrm{m} 2$ and chi-square $\mathrm{X} 2$ are reported in brackets. $* * *$ significant at $0.1 \%, * *$ significant at $1 \%$, and $*$ significant at $5 \%$.

\section{CONCLUSION}

This paper studies the relationship between the most two important factors for bank survival. We find that the relationship between bank credit risk and bank liquidity risk is positive. The paper also finds that bank capital is an important factor of bank liquidity risk as it initially increases the liquidity risk and with more capital buffers and build-ups it decreases the liquidity risk. Larger banks tend to have more liquidity risk; more net-interest income leads to more liquidity risk, and more non-interest income leads to less liquidity risk. Bank inefficiency is related to liquidity risk and macroeconomic environment (inflation and sovereign debt) are affecting liquidity risk negatively.

\section{REFERENCES}

Allen, F. \& Santomero, A. M. (1997). The theory of financial intermediation. Journal of Banking \& Finance, 21(11):1461-1485.

Arellano, M. \& Bover, O. (1995). Another look at the instrumental variable estimation of error components models. Journal of Econometrics, 68(1):29-51.

Arellano, M. \& Bond, S. (1991). Some tests of specification for panel data: Monte Carlo evidence and an application to employment equations. The review of economic studies, 58(2):277-297.

Berger, A. N., \& Bouwman, C. H. (2009). Bank liquidity creation. Review of Financial Studies, 22(9), 3779-3837.

Blundell, R. \& Bond, S. (1998). Initial conditions and moment restrictions in dynamic panel data models. Journal of econometrics, 87(1):115-143.

De Haan, J., Oosterloo, S., \& Schoenmaker, D. (2009). European financial markets and institutions. Cambridge University Press.

Diamond, D.W. \& Rajan, R. G. (2000). A theory of bank capital. The Journal of Finance, 55(6):2431-2465.

Distinguin, I., Roulet, C., \& Tarazi, A. (2013). Bank regulatory capital and liquidity: Evidence from US and European publicly traded banks. Journal of Banking \& Finance, 37(9), 3295-3317.

Imbierowicz, B. \& Rauch, C. (2014). The relationship between liquidity risk and credit risk in banks. Journal of Banking \& Finance, 40:242-256.

Louzis, D. P., Vouldis, A. T., \& Metaxas, V. L. (2012). Macroeconomic and bank-specific determinants of non-performing loans in Greece: A comparative study of mortgage, business and consumer loan portfolios. Journal of Banking \& Finance, 36(4):1012-1027.

Ratnovski, L. (2013). Liquidity and transparency in bank risk management. Journal of Financial Intermediation, 22(3):422-439.

Windmeijer, F. (2005). A finite sample correction for the variance of linear efficient two-step GMM estimators. Journal of econometrics, 126(1):25-51. 